\title{
Erratum to: Biochemical persistence in thyroid cancer: is there anything to worry about?
}

Fabián Pitoia $\cdot$ Erika Abelleira $\cdot$ Hernán Tala $\cdot$

Fernanda Bueno $\cdot$ Carolina Urciuoli •

Graciela Cross

Published online: 18 February 2014

(C) Springer Science+Business Media New York 2014

Erratum to: Endocrine

DOI 10.1007/s12020-013-0097-6

The article originally published with the author names reversed. They appear correctly here.

The online version of the original article can be found under doi: 10.1007/s12020-013-0097-6.

F. Pitoia $(\varangle)$ - E. Abelleira · F. Bueno · C. Urciuoli · G. Cross División of Endocrinología, Hospital de Clínicas, University of Buenos Aires, Córdoba 2351, 5th floor, Buenos Aires, Argentina e-mail: fpitoia@intramed.net

H. Tala

Clínica Alemana de Santiago, Universidad del Desarrollo,

Santiago, Chile 